\section{Toplumun Turist Rehberliği Algısı: Ekşi Sözlük Üzerine Bir Inceleme}

\author{
Grant Altay Taşkın ${ }^{1^{*}}$ \\ ${ }^{1}$ Aksaray Üniversitesi, Turizm Fakültesi, grantaltaytaskin@aksaray.edu.tr, ORCID 0000-0001-6689-7728
}

Öz

Bu çalışmanın amacı, toplumun zihninde oluşan turist rehberliği algısını anlamaya çalışmaktır Geçmişten günümüze insanlar seyahat ve turizm hareketine katılmakta, gezip gördüğü yerleri anlamlandırmak ve tatillerinin bir deneyime dönüşmesi için turist rehberlerine ihtiyaç duymaktadır. Bu çalışmada sadece rehberli turlara katılım sağlayan kişilerin değil daha önce grup ile seyahat etmemiş fakat kulaktan dolma da olsa aklında bir turist rehberi figürü oluşan kişilerin de algılarını gün yüzüne çıkarmak hedeflenmiştir. Çalışmada Ekşi Sözlük platformunda 2001 yılından bu yana turist rehberliğine dair yapılmış tüm yorumlar içerik analizi yöntemiyle değerlendirilmiştir. Ayrıca toplumun algısı hakkında fikir edinilmesinin amaçlandığı bu çalışmada kesin bir yargı çıkarmanın da doğru olmayacağı dikkate alınmalıdır. Araştırma sonucunda toplumun turist rehberlerine karşı yüksek oranda olumsuz bir bakış açısına sahip oldukları görülmüştür. Toplumun turist rehberlerini; insanlarla uğraşmak zorunda kalındığından zor, müşterilerden komisyon almaya hevesli oldukları için hanutçu ve bilmedikleri konularda bile yanıt vermekten imtina etmedikleri için yalancı ve yetersiz kişiler olarak gördükleri sonucu çıkartılmıştır. Ayrıca mesleği yalnızca tanımlama yoluna giderek nötr cevaplar veren bir kesim de varken bu konudaki olumlu yanıtlar ise entelektüel birikimi olan, keyifli, prestijli ve profesyonel bir meslek şeklindedir.

Anahtar Kelimeler: Turist Rehberliği, Ekşi Sözlük, Toplumsal Algı

\section{Society's Perception of Tourist Guidance: An Investigation on Ekşi Sözlük}

\section{Abstract}

The aim of this study is to try to understand the perception of tour guiding that occurs in the mind of society. People, from past to present participate in the travel and tourism movement, they need tour guides to make sense of the places they visit and turn their vacation into an experience. In this study, it is aimed to reveal the perceptions of not only the people who participated in guided tours, but also those who have not traveled in a group before, but who have a tourist guide figure in mind. In the study, all comments on tour guidance since 2001 on the Ekşi Sözlük platform were evaluated using the content analysis method. In addition, it should be taken into account that it is not correct to make a definite judgment in this study, in which it is aimed to gain an idea about the perception of the society. As a result of the research, it is seen that the society has a high negative perspective towards tour guides. It has been deduced that society finds the job of tour guides difficult because they have to deal with people, they are brokers because they are enthusiastic to receive commissions from customers, and they see them as liars and inadequate because they do not refrain from responding even to unfamiliar matters. In addition, while there is a segment that gives neutral answers only by defining the profession, the positive answers in this regard say that it is a pleasant, prestigious and professional profession with intellectual accumulation.

Keywords: Tourist Guidance, Ekşi Sözlük, Social Perception
Araştırma Makalesi

Cilt 5, Sayı 1, 2021 ss. $48-60$

Gönderim : 21.09.2020

1. Düzeltme: 06.11 .2020

2. Düzeltme: 01.01.2021

Kabul Tarihi: 21.01.2021

Research Article

Vol 5, No 1, 2021

pp. $48-60$

Received : 21.09.2020

Revision1: 06.11.2020

Revision1: 01.01.2021

Accepted: 21.01.2021

Önerilen Atıf/Suggested Citation

Taşkın, G.A. (2021). Toplumun Turist Rehberliği Algısı: Ekşi Sözlük Üzerine Bir İnceleme. Güncel Turizm Araştırmaları Dergisi, $5(1), 48-60$.

\footnotetext{
**Sorumlu yazar e-posta: grantaltaytaskin@aksaray.edu.tr
} 


\section{GíRIŞ}

Turizm sektöründe müşterilerle doğrudan iletişim halinde olduğundan dolayı turist rehberinin önemi oldukça yüksektir. Ayrıca ülkeye gelen turistlerin tekrardan geri dönme motivasyonu edinmesinde de bir pay sahibidir. Bu bağlamda rehberlik mesleğini icra eden kişiler dışında turist rehberliğinin ne olduğuna dair insanların bilgi sahibi olması ve akıllarında güzel bir profil oluşması oldukça önemlidir. Son yıllarda artarak devam eden sosyal platformlara ilgi bu mecraları neredeyse bir pazarlama aracına döndürmüş durumdadır. Daha önce keşfedilmemiş koyların meşhur olması, en güzel yemeğin nerede yeneceği, en güzel kahvenin nerede içileceği ile başlayan furya meslek grupları için bile bir imaj çizebilmektedir. Türker ve Özaltın Türker'e (2017) göre sosyal medya platformları rehberlerin pazarlama için aktif kullanmaları gerek bir mecradır ve turistler gittikleri destinasyonlarda rehberlerini zaman zaman internet araştırması ile bulmaktadırlar.

Özellikle yerli turistlerin profesyonel bir turist rehberi ile gezmek istemesinde internet ortaminda gördüğü reklamlar ve okuduğu olumlu/olumsuz yorumlar oldukça etkilidir. Turizm hareketine katılmak isteyen kişiler seyahat acentelerinden paket tur alabilecekleri gibi, doğrudan rehber ile iletişime geçerek rehber-müşteri sözleşmesi imzalayarak da tur gerçekleştirebilirler.

Bu çalışmada açlan başlıklar altında yorum yapmaya, fikir bildirmeye olanak sağlayan Ekşisözlük platformundaki rehberliğe dair yorumların tümü incelenerek toplumdaki turist rehberliği mesleği algısı hakkında fikir sahibi olunmaya çalışılmıştır.

\section{KAVRAMSAL ÇERÇEVE}

Profesyonel turist rehberleri; 6326 sayılı kanunda münferit veya gruplar halindeki turistleri, talep ettikleri dillerde ülkenin doğal, tarihi ve kültürel alanlarını turizm politikaları ışı̆̆ında tanıtarak gezdiren kişi olarak tanımlanmıştır (TUREB, 2012). Turist rehberliğine dair farklı birçok tanım literatüre geçmiştir. Cohen'e (1985) göre birçok rolde bulunabilen turist rehberinin başlangıçtaki tanımı yol gösterici ve akıl hocasıdır. Ap ve Wong (2001) ise turist rehberlerini destinasyon çekicilikleri ve kültürleri hakkında bilgi seviyesi yüksek kişiler olarak tanımlarken ayrıca turistler için bir gezinin deneyime dönüşmesini sağlayan kişi olarak vurgulamaktadır. Bu konuda Dünya Turist Rehberliği Birlikleri Federasyonu'na (WFTGA) göre ziyaretçilere tercih ettikleri dilde, bağlı oldukları kurum tarafından yetki verilen bölgelerde doğal ve kültürel anlamda bilgi veren kişiler olarak tanımlanmaktadır. Ayrıca turist rehberleri sadece turun gerçekleştiği gün içerisinde değil bir sonraki turlar için bile müşteriler üzerinde etki bırakabilmektedir (Kong, 2014:19).

Türkiye'de toplam turist rehberi sayısı $11110^{\prime}$ dür. Bu rehberlerden aktif olarak mesleğini icra edenlerin sayısı 8257 , eylemsiz ${ }^{1}$ statüsünde olanların sayısı ise $2853^{\prime}$ tür

\footnotetext{
${ }^{1}$ Eylemsiz Turist Rehberi: Ruhsatname sahibi olup çalışma kartı olmayan, bir başka deyiş ile mevcut sene içinde rehberlik yapmayı düşünmeyerek yıllık aidatın beşte birini ödemek koşuluyla hakkını saklı tutan kişidir.
} 
(TUREB, 2020). Dolayisıyla mevcut turist rehberlerinin \%25'inden fazlasinin mesleğinden uzaklaşma kararı aldığı görülmektedir. Turist rehberlinin Türkiye' de çok fazla değer göremiyor olması veya farklı kişisel sebeplerden dolayı hergün mesleğini bırakan bir çok kişi bulunmaktadır. Bu konuda etraflıca bilgi sahibi olmak adına literatürdeki bazı çalışmalarda araştırmacıların, rehberlerin sorunlarını kendilerinden dinlemek adına görüşme ve anketler uyguladığı görülmektedir (Alrawadieh, Gürel, Dinçer, ve İstanbullu Dinçer, 2020; İlhan ve Soybalı, 2018; Gökdemir ve Hacıoğlu, 2018; Köroğlu, Ulusoy Yıldırım, ve Kılıç, 2020).

Durumlara yalnızca rehber gözünden bakmak eksik bir bakış açısı olabilmektedir. Hwang, Kim, Lee ve Sahito (2020), misafirlerin destinasyonu beğenmelerinin rehberi de beğenecekleri anlamına gelmediğini belirtmektedir. Dolayısıyla işini iyi yaptı̆̆ını varsayan rehberlerin toplumda her zaman hissettikleriyle doğru orantılı algılanmadı ̆̆ ortadadır. Bu bağlamda turist rehberlerinin problemlerinin veya artı yönlerinin yalnızca kendi açlarından değil ayrıca turistlerin gözünden de görülmesi gerektiği düşünülmektedir. Bu kapmsamda turist rehberliği ile ilgili açılan başlıklar altındaki yorumlar anlam taşımaktadır. Türkiye'de insanların görüş ve önerilerini yazmak için çeşitli sözlük adı verilen platformlarda yazarlık yaptıkları bilinmektedir. Bunlardan en sık kullanılanı Ekşisözlüktür.

Ekşisözlük, 15 Şubat 1999 yılında kurulmuş olan "her türlü konu ve kavram hakkında, kayıtlı yazarların yorumların içeren katılımcı sözlük tarzında ă̆ sayfası olup, web sitesi Türkiye'deki katılımo sözlükler arasında en fazla toplam ve aylık tanım yapılan sitedir" şeklinde tanımlanan bir sosyal platformudur (Ekşisözlük, 2020). Sitede üyeliği olan kişiler sözlük yazarı, yapılan yorumlar ise entry olarak adlandırılmaktadır. Bu çalışmada "entry" kelimesi yerine Türkçe'de karşılık gelmesi en uygun görülen "yorum" kelimesi kullanılacaktır. Tüketicilerin turizm hareketine katılmakta internet üzerindeki sosyal mecralarda yaptıkları araştırmalar oldukça önemli bir yer tutmaktadır (Tuncer ve Taşkın, 2020:2058) . Toplumun nabzının ölçülmesi adına iyi bilinen Facebook, İnstagram, Twitter ve YouTube analizlerinin yanında akademik alanda son dönemde Ekşisözlük üzerine de birçok araştırma düzenlenmiştir (Kaya , 2020; Yıldırım, 2020; Söğüt , 2020).

Turist rehberliği ile ilgili çeşitli platformlarda yapılan yorumların incelenmesinin hem mesleğin mevcut sorunlarına hem de mesleğe karşı olan toplumsal bakış açısına 1şık tutacağ1 öngörülmüştür. Araştırmacının turist rehberliği yaptığı dönemde gruplardan aldığı geri dönüşler bu çalışmanın yapılması adına ilham kaynağı olmuştur. Tura ilk defa katılan misafirlerin rehberler hakkında önyargıları olduğu fakat turun ardından bu önyargının yerini güzel izlenimlere bıraktığı görülmüştür. Rehberlere karşı var ise olumsuz tutumun bir diğer sebebi ise rehberlerin; çevreyi tanıtmak, misafirlerin güvenliğini sağlamak, acentenin haklarını korumak gibi birçok farklı görevi aynı anda yürütmek zorunda olmalarıdır (Liljeblad, 2020).

Araştırmanın temel problemi turist rehberliğine karşı yerel halkın olumlu/olumsuz tutumlarının değerlendirilmesi ve mesleğe dair oluşabilecek önyargıların önüne geçilmesi adına öneriler geliştirilmesidir. 


\section{YÖNTEM}

$\mathrm{Bu}$ çalışma nitel araştırma yöntemleri kullanılarak yürütülmüştür. Çalışma kapsamında elektronik ortamda konular üzerinde birbirinden bağımsız katılımcıların yorumlar ve değerlendirmeler yazabildiği Türkiye'de en sık kullanılan platformlar arasında yer alan "Ekşisözlük" ismindeki mecrada "turist rehberliği" ve "turist rehberi" başlıkları altındaki yorumlara içerik analizi uygulanmıştır. İçerik analizi, toplanan verilerin düzenlenmesi ve açılanabilmesi adına kavramlarla ilişkilendirilebilmesi işlemine verilen isimdir (Yıldırım ve Şimşek, 2018). Araştırmada turist rehberliği faaliyetini birebir veya dolaylı yoldan deneyimlemiş kişilerin yaşanmışlıkları ve ifade ettikleri görüşleri dikkate alınmış olduğundan çalışma fenomenolojik bir desene sahiptir. Fenomenoloji, temeli felsefe ve psikoloji alanlarına dayanan (Cresswel, 2017), insanların deneyim ve tecrübeleri üzerine dayanan bir nitel araştırma desenidir (Merriam, 2018).

Konu başlıklarına ait ilk yorum tarihi olan 04.08.2001 ile son yapılan yorum tarihi olan 19.05.2020 tarihi arasındaki tüm yorumlar incelenmiştir. Siteden yorumların alındığ erişim tarihi 15.06 .2020 'dir ve sonrasında yapılan veya yapılacak yorumlar çalışma sınırlarının dışında tutulmuştur. İki başlık altında yapılan yorum sayısı 93'tür. Anlamsız veyahut kötü söz içeren yorumların ayıklanması sonucu toplamda incelenen yorum sayısı 72'dir. Gaus, MacQueen ve Namey'den aktaran Creswell (2017), nitel bir çalışmada verinin tamamı her zaman kullanılmayabilir araştırmacı zaman zaman belirli notlara yoğunlaşabilir ve bu işleme veri ayıklama süreci denmektedir şeklinde belirtmiştir.

İsminde sözlük geçmesine rağmen verilen bilgilerin herhangi bir doğruluk içermek zorunda olamaması, kişilerin deneyim ve düşüncelerini özgürce paylaşabiliyor olması bu platformun seçilmesinde tercih sebebidir. Buradaki tüm yorumlar deşifre edilerek nitel veri analizi programında işlenmiş, temalar ve kodlar olarak sınıflandırılmıştır. Kodlama işlemi yazıya dökülmüş verilerin konuya göre sınıflandırılmasına verilen isimdir (Merriam, 2018). Analizin değerlendirilmesinde; kelime bulutu, kod matris tarayıcısı ve kavram haritasından faydalanılmışır. Dikkate alınmalıdır ki Ekşi Sözlük sitesinde yer alan yorumlar toplumun algısı hakkında fikir vermekte fakat araştırmacı tarafından kesin bir yargıya varma amacı taşımamaktadır.

\section{BULGULAR}

Araştırmadan elde edilen veriler değerlendirildiğinde sözlük yazarlarının "turist rehberliği" veya "turist rehberi" başlığını gördüklerinde yapmış oldukları yorumlar başlangıçta olumlu, olumsuz ve nötr adında üç tema altında toplanmıştır. Buradaki tüm yorumlar incelendiğinde ele aldığımız kişilerin akıllarında canlanan rehber profili için olumsuz bir bakış açısına sahip oldukları görülmüştür. Görüşlerin bazıları daha önce turlarda bulunmuş kişilerden, bazıları yakınları rehber olanlardan bazıları ise kişilerin yalnızca çevresel duyumlarından kalma algılarından oluşmaktadır.

Analiz edilen verilerde kişilerin daha fazla hangi kavramlar üzerinde durduğu, turist rehberi denince akıllarında ilk canlanan kelimenin hangisi olduğunu anlamak adına 
çalışmaya ait kelime bulutuna başvurulmuştur. Şekil 1'deki kelime bulutunda yorum yapan kişilerin en sık kullandığı kelimeler daha büyük punto ile gösterilmektedir.

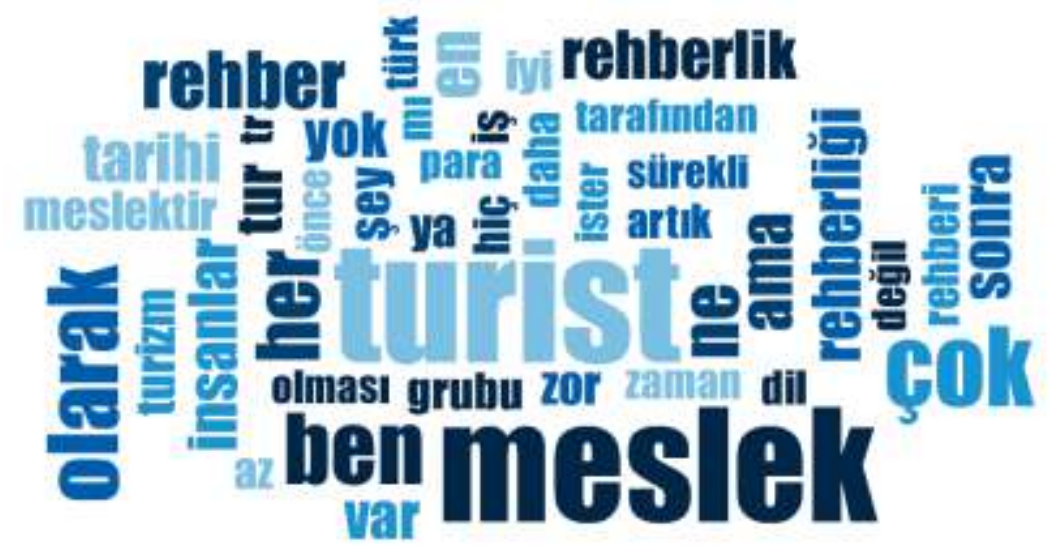

Şekil 1: Kelime Bulutu

Bu kapsamda bağlaçlar ve ekler gibi anlamsız sözcük yapıları analizin dışında bırakılırsa kullanıcıların; "turist, meslek, rehberlik, zor, az, para, çok, tarihi, insanlar, tarafından, sürekli” kelimelerini kullanmaları oldukça ilgi çekicidir. Kişilerin turist rehberliğini gerçek bir meslek olarak görmeleri, ekonomik boyutu hakkında yorum yaptıkları ve insanlar ile olumlu/olumsuz iletişim halinde oldukları varsayımında bulunulabilir.

Nitel veri analiz programında 72 farklı kişiye ait yorumlar 83 biçimde kodlanmıştır. Temalar ve alt kodların düzenlendikten sonra görüş bildiren kişilerin konu yoğunlukları Şekil 2'deki kod matris tarayıcısında farklı boyutlardaki kare işaretleri ile gösterilmiştir.

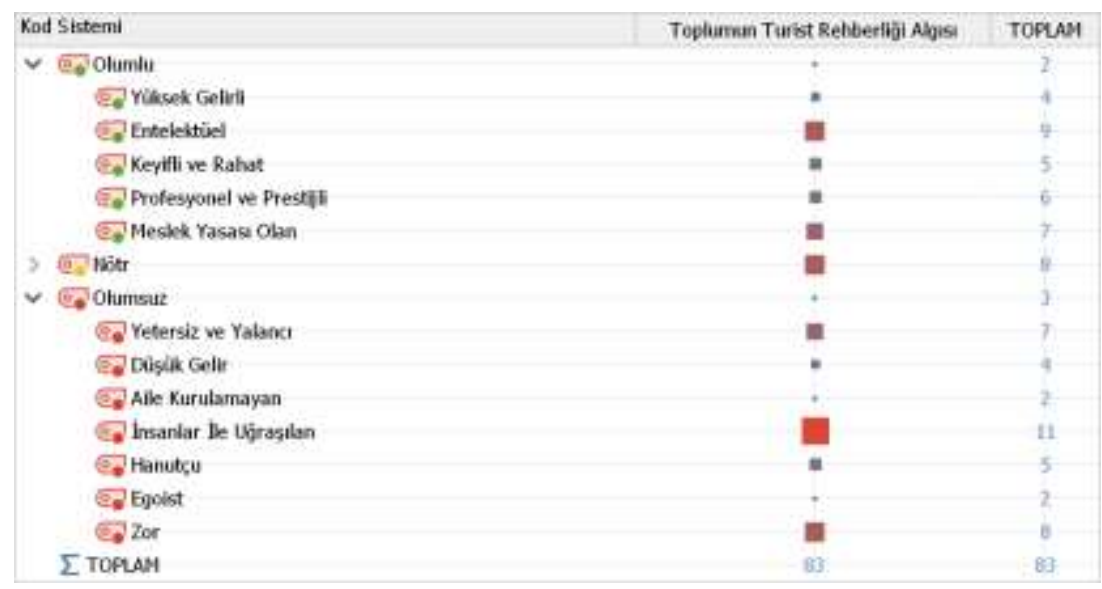

Şekil 2: Kod Matris Tarayıcısı

Kişilerin olumlu olarak zihinlerinde oluşan rehber tanımının bilgi düzeyi yüksek, toplumda saygınlığı olan profesyonel fakat aynı zamanda rahat bir meslek olduğu görülmektedir. Nötr yorumlarda genellikle mesleğin tanımı yapılmakta veya mesleğin diğer mesleklerde karıştırıldığından bahsedilmektedir. Konuya ait olumsuz yorumlarda ise sorunlu insan gruplariyla ilgilenmek zorunda olunan, komisyon peşinde koşulan ve bazen yetersiz ya da yanlış bilgi veren insanların icra ettiği bir 
meslek algısına sahiptir. Katılımcıların yanitlarının temalar ve alt kodlar ile detaylandırılmış hali Şekil 3’ te gösterilmektedir.

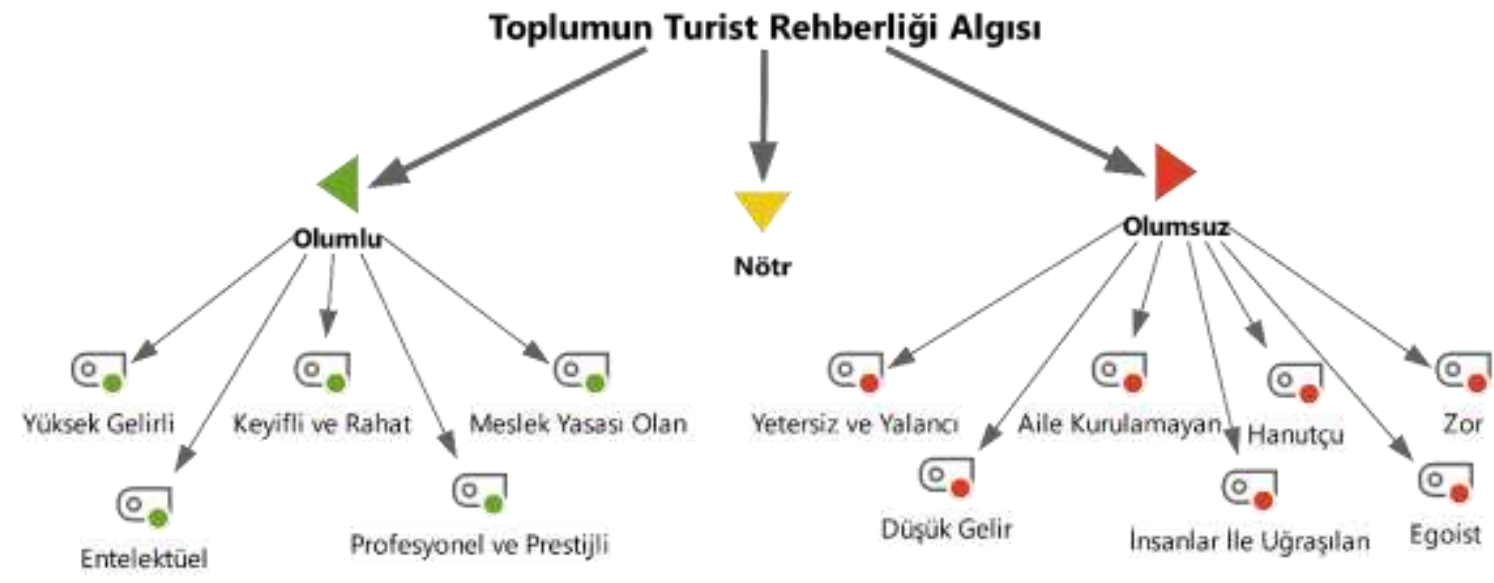

Şekil 3. Kavram Haritası

\section{Mesleğe Dair Olumlu Algılar}

Sözlükte fikrini ortaya koyan kişilerin olumlu yorumları önem sırası dikkate alınarak; "entelektüel, meslek yasası olan, profesyonel ve prestijli, keyifli ve rahat ve yüksek gelirli" şeklinde sıralanmaktadır.

\section{Entelektüel}

Turlara daha önce katılım sağlamış kişilerce bilinir ki bir rehber seyahat boyunca devamlı ziyaretçilere destinasyonlar hakkında bilgiler vermektedir. Bu gözlemler ve çevreden duyumlar ile kişiler rehberliği bilgi ve kültür seviyesi yüksek, entelektüel bir meslek olarak görmektedirler. Bu konuda bildirilen görüşlerden bazıları şunlardır:

"Hayatı boyunca; tarih, mitoloji, arkeoloji ve politika gibi konularda aldığı derslerin sonu gelmeyen, ders veren kanl canl, vokal gezi rehberi."

"Çok okuyan ve genel kültürü yüksek biri olarak acaba becerebilir miyim diye merak ettiğim meslek dal.."

"Hayatı boyunca ayaklı ansiklopedi, tek cilt değil komple ansiklopedi seti olması gereken insan"

"Nitekim bu mesleği icra eden kişilerin dünyanın bir ucundan gelmiş turistlere, antik Efes şehrini gezdirmek için Yunan ve Roma tarihi, Kapadokya'yı gezdirebilmek için yanardă̆lar, erken Hristiyan tarihi, İncil, fresk okuma, Gelibolu milli parkın gezdirebilmek için savaş tarihi, Atatürk, Türk tarihi, Avrupa tarihi, topografya, Konya'yı gezdirebilmek için Mevlana ve sufi felsefesi, Ankara'yı gezdirebilmek için devlet ve politika sistemimiz, kurtuluş savaşı tarihi, Hititler, buradaki büyük müzeyi gezdirebilmek için Anadolu'dan gelmiş geçmiş tüm ırklar vb. ile ilgili bilgi sahibi olabilmesi, bunları birde çalıştı̆̆ı yabancı dilde akıcı bir şekilde anlatabilmesi gerekir." 


\section{Meslek Yasası Olan}

Profesyonel turist rehberliği mesleği konusunda birçok kişide farkındalık olduğu görülmektedir. Mesleğin yasa ve kanunlarla standartlara bağlandığı ve ayrıca meslek kuruluşlarının da varlığı sözlük yazarları tarafından şu ifadeler ile anlatılmıştır:

"Değişen turizm mevzuatı ile profesyonel turist rehberliği kurslarında beş ile yedi ay arası eğitim alması gereken, eğitim sonrasında da en az otuz günlük yurtiçi gezisine çıkılması gereken meslektir. Bu gezi sonrasi meslek dillerinden sinav olurlar ve kokart lisanslarma ulaşırlar. Bunun dışında üniversitelerin turist rehberliği bölümlerinde iki veya dört yıl okuduktan sonra, mezun olurlar. Mezuniyet ve Türkiye gezisini bitirip KPDS sinavma girerek yetmiş puan alarak kokartlarnna sahip olurlar"

"6326 sayılı turist rehberliği meslek kanunu ile tanımlanan ve korunan meslek grubu."

"Bir de birlikleri vardır bunlarm, TUREB'tir adı."

\section{Profesyonel ve Prestijli}

Görüşlerini ifade eden kişiler bu mesleğin ciddi bir iş olduğunu ve her isteyenin serbestçe yapamayacağını belirtmektedirler. Yalnızca yasalarca belirlenen şartları ve eğitimleri yerine getiren kişiler bu mesleği profesyonel olarak icra edebilmektedir. Aynı zamanda rehberlik toplumda statüsü olan, önemli bir meslek olarak görülmektedir. Bu hususta bazı ifadeler şu şekildedir:

"Turist rehberininki, amatörce yapılacak bir meslek değildir; olmamalıdır."

"Ülkemizde turist rehberliği bir meslektir. Öyle her önüne gelen rehberlik yapamaz. Herhangi biri sırf yabanct dil biliyor diye bu mesleğ i icra edemez, ya da bir grubu toplayıp onlara tur düzenleyip anlatım yapamazsınız. Meslek profesyonelce yapılır. Profesyonel turist rehberi kokart sahibidir"

"Çoğu insanın ne iş yaptığını tam olarak bilmemesine ve mesleksiz olarak tanımlamasına karşın, doğru zamanda doğru dilleri öğrendiği takdirde hem üne hem de paraya kavuşabilecek olan, aslında önemli bir mesleği yerine getiren kişidir."

\section{Yüksek Gelirli}

Kişiler gözlemledikleri üzere turist rehberlerini yüksek maddi gelir elde eden, dolgun maaşlı, satın almak istediği şeyleri gönlünce satın alabilecek derece ekonomik durumu müsait kişiler olarak görmektedir. Bu bağlamda görüş bildirenler aşağıda verilmiştir:

“Tamamen benim yapmak istediğim şeyler üzerine kurulu. Sakın ha küçümsemeyin dilciler! maaşı cidden çok iyidir. Tarihinin coğrafyanın ve yabancı dilinin iyi olması şarttır. Gerisi sana son model bir Audi RS getirir."

"24 saat mesai halinde olan, yeri geldiğinde birkaç günlük çalışma sonunda beyaz eşya, araba, vs. sahibi olabilecek tek meslek grubu."

"Eskiden gelirleri epey yüksekti, 80'lerde her sezon bitimi düzgün semtlerden bir daireyi kenara atanlar olurdu ki zaten cimrice yaşanacak meslek değildir, kıyafet, yemek, içki, abla derken ucuz yaşamazlardl." 


\section{Mesleğe Dair Nötr Algılar}

Mesleğe dair kimi görüşler ise olumlu ve olumsuz olarak kategorize edilen yorumlardan ayrışmaktadır. Başlığın altına yalnızca mesleği tanımlamak için yorum yazmış olan kişiler mevcutken kimisi mesleğin halk dilindeki anlamını kimisi ise tercümanlık ile sıklıkla karıştırıldığından bahsetmiştir. Bu kapsamda görüş bildirenler şu şekildedir:

"Halk arasında turculuk olarak anilan meslek."

"Asıl adı tur rehberliğidir."

"Türkiye'de bir grup insanın tercümanla farkını bilmediğ $i$ yüzden tercümanlara yakıştırdı $\breve{g} \imath$ fakat çok farklı bir bilgi birikimi gerektiren meslek"

"Yeminli tercüman olduğunuzu söyleyince insanların, yaptı̆̆ınızı zannettiği iş."

$\mathrm{Bu}$ yorumlara ek olarak mesleğin olumlu/olumsuz hangi yöne evirileceğini rehberin kendisinin belirlediği düşüncesi de dikkate değerdir. Yorumu yapan kişinin görüşü aynen şu şekildedir:

"Max Royal'de ücretsiz kalanları da vardır, apartmandan bozma şehir otellerinde müşteriyle aynı odada kalanı da... o yüzden bu işi yaptınız mı en iyisi olun."

\section{Mesleğe Dair Olumsuz Algılar}

Sözlükte fikrini ortaya koyan kişilerin olumsuz yorumları önem sırası dikkate alınarak; "insanlar ile uğraşılan, zor, yetersiz ve yalancı, hanutçu, düşük gelir ve aile kurulamayan" şeklinde siralanmaktadır.

\section{Insanlar ile Ŭgraşılan}

Doğrudan insan-insan kontaklı bir meslek olan turist rehberliği için yorum yapan kişiler tarafından da iletişim problemleri sıkça vurgulanmıştır. Turist rehberliğine karşı olumsuz bakan kişiler düşüncelerini; turistlerle devamlı sorun yaşanma ihtimali olan, alakasız sorularla çok fazla karşı karşıya kalan ve bitmek tükenmek bilmeyen isteklerini gerçekleştirmek zorunda kalan kişi olma şeklinde sıralamıştır. Söz konusu görüşler aşağıdaki gibidir:

"Adının turist bakıcılığı olarak değiştirilmesini önerdiğimiz meslek gibi bir şey"

"Dışarıdan "aman ne güzel eğleniyorlar, üstüne de para alıyorlar" gibi görünmektedir. Lakin kimse düşünmemektedir $k i$ bu insanlar gerektiğinde gecenin 03:00'ünde patlayan bir apandistin ardindan hastanelerde turist pesinde koşup ertesi gün gruba meryemana anlatmakta..."

"İçlerinden bir tanesini delirttiğim meslek grubu. Sene 2000 yer Paris. Sevgili turist rehberimiz bizi gezdirecek. Başına geleceklerden habersiz. Genç daha, hevesli, seviyor işini. Sevilmeyecek gibide değil. En azından o zamana kadar." 
Mesleğin dışarıdan bakıldığı zaman gezerek para kazanmak olarak görünebileceği fakat az çok bilgisi olan kişilerin turist rehberliğini yorucu ve zor bir meslek olarak gördükleri anlaşılmaktadır. Bu kapsamda şu görüşler ifade edilmektir:

"Zevkli bir meslek gibi görünmesine rağmen aslında çok yorucu ve zaman zaman da çok sıkıcı olan meslektir."

"Her meslek gibi dışarıdan lay lay lom ve havadan para kazanıldığı düşünülen iştir. Aslında yeri gelir garsonluk, yeri gelir çobanlık yapıp sürüyü idare etmeniz gerekir. Alınan rakamlar da çok fazla değildir. Çoğu zaman gün kurtarllır."

"Rehberlik zor iştir. Nezaket ister, bilgi ister, ilgi ister, güleryüz ve çaba ister. İster oğlu ister yani."

\section{Yetersiz ve Yalancı}

Sözlük yazarlarının turist rehberine karşı izlenimleri genellikle bilmedikleri konularda yanlış bilgi vermekten çekinmedikleri yönündedir. Turist rehberlerinin bilgi olarak çok da yeterli olmadığını da düşünen yorumcular şu görüşlerde bulunmuşlardır:

"Wikipedia'dan, wikitravel'dan bilgiler toplanır sonra turistlere aktarllır. Az bir şey araştırmacı turist bir soru sorduğunda kem küm edilir. İşte biz buna turist rehberliği diyoruz."

"Sallamanın en güzel örneği konusunda master yapmış insanlardır bu mesleği icra edenler. Turistlerin hoşuna gitsin diye ash astarı olmayan bir sürü absürt bilgiyi turistlere yedirirler."

"Efes'te rastlanılan ve artık beyni güneş altında şapkasız dolanmaktan lop yumurta kıvamına gelmiş bıngıldak ile idare eden bir rehberin sözleri şu şekildedir; you see this stone? This is old. This is very old. Let me say 1000 years, let you say 2000 years. It is that old"

\section{Hanutçu}

Geçmişten günümüze rehberlerle birlikte adı çok anılan hanutçuluk (komisyonculuk) sözlük yazarları tarafından da rehberlerle sıklıkla bağdaştırılmıştır. Rehberler, müşterileri üzerinden para kazanmaya çalışan veya insanları dolandırmaya çalışan kişiler olarak gösterilmiştir. Söz konusu yorumlardan bazıları şunlardır:

"Halk tarafindan pek sevilmeyen bir meslek grubudur. Hem gezip hem para kazanan bu insanlar bir de turistleri kazıklamaya çalıştığı için zaman zaman insanlarda nefret duygusu uyandirur"

"Turistleri kazıklama ve her şeyden komisyon alma işi olmasa asılda güzel meslek."

"Aralarına tur katılımcıları üzerinden sağladıkları avantalarla yolunu bulmayı adet edinmiş şahısları bolca barındıran meslek grubu"

\section{Düşük Gelir}

Mesleğin olumlu yönlerinde olduğu gibi olumsuz yönlerinde de gelir ile ilgili yorumlar söz konusudur. Ülkemizdeki rehberlerin yurtdışındakilere karşı daha az kazandığı, sezonda kazanılanın tüm yıla yetmediği gibi görüşler mevcuttur. Yapılan yorumlardan bazıları şunlardır: 
"Ülkemizde çok fazla kazanılmasa da dış ülkelerde maaşı iyi olan bir meslektir."

"Kazanılan para miktarı çok gibi görünse de bu miktarn 12 aya yayılacağı göz ardı edilmemelidir."

İçinden geçilen ekonomik kriz ve buhranlar da rehberlerin maddi olarak zor zamanlar geçirdiği durumlardır. Bu konuda bir yorum ise "Şu an Türkiye'de zor durumda olan adamdır." şeklindedir.

\section{Aile Kurulamayan}

Sürekli seyahat halinde olunan bir meslek olduğu için turist rehberliği dışarıdan aile kurmaya çok müsait olmayan bir meslek grubu olarak görülmektedir. Bu konudaki görüşler şu şekildedir:

"Öncelikle geceniz gündüzünüz olmuyor maalesef. Bu mesleği icra ederken bir aile kurmak gerçekten çok zor bir hal alyor."

"Düzenli bir aile hayatı şehir dışı yapılan turlar yüzünden olmaz."

\section{TARTIŞMA, SONUÇ VE ÖNERILER}

Araştırmadan elde edilen sonuçlara göre turist rehberliği denildiğinde kişilerin aklında genellikle olumsuz bir algı oluşmaktadır. Yorumlar incelendiğinde kişilerin zaman zaman katıldıkları turlarda deneyimledikleri rehberlik algısını zaman zamansa kendileri rehberlik yapacak olsalar hangi özelliklerin onlara daha uygun olacağını belirtmek istemişlerdir. Kullanıcıların kendilerince rehberliğin tanımını yaptıkları da görülmüştür.

Olumsuz sonuçlar değerlendirildiğinde, turist rehberlerine yapılan online şikayetlerin ele alındığı bir çalışmada; kibirlilik, yetersiz bilgilendirme, satış boyutu gibi sonuçlar bu çalışmayla birebir örtüşmektedir (Temizkan \& Ar, 2017). Bir başka çalışmada ise Karamustafa ve Kılıçhan (2019), turist rehberliği mesleki sorunlarından birini bu çalışmaya benzer olarak turistlerle yaşanan iletişimsel sorunlar olarak ortaya koymuştur.

Çalı̧manın ilgi çekici sonuçlarından bir tanesi ise turist rehberliği mesleğinin kanun ve yönetmeliklerle düzenli hale getirildiğidir. Kişilerin rehberleri hem maddi durumu çok iyi olan hem de düşük gelire sahip kişiler olarak gördükleri şaşırtıcı bir sonuçtur. Toplumsal olarak turist rehberlerinin ekonomik durumları hakkında yaygın ve geçerli bir bilgi olmadığ yazarlarının turist rehberliğini rahat bir iş olarak gördükleri ve bu işi kendilerinin de kolaylıkla icra edebileceklerini vurguladıkları görülmüştür. Ayrıca tur boyunca neredeyse sorulan tüm sorulara cevap veren rehberler, insanların gözünde entelektüel seviyesi çok yüksek kişeler olarak belirmektedir.

Demirbulat'ın 2014'te ele aldığı iş- aile çatışmasını konu alan çalışmasında bu çalışmaya taban tabana zıt olarak turist rehberliğinin ailevi açıdan kendilerine hiçbir engel teşkil etmediği sonucuna ulaşılmıştır. Fakat bu çalışma göstermektedir ki rehberlik mesleği insanların zihninde aile kurmanın zor olduğu bir meslek grubudur. 
Meslekte ileriye gitmek ve toplumun olumsuz algılarını düzeltmek için sosyal mecralar oldukça büyük öneme sahiptir ve bu bağlamda elektronik ortamdaki şikâyet ve önerilerin eleştiri olarak kabul edilerek üzerine gidilmesi, var ise yapılan yanlışların düzeltilmesi için çaba sarf etmek gerekmektedir. Turist rehberliğinin kimi sözlük yazarları tarafından profesyonel ve prestij sahibi bir meslek olarak görülmesi değerli bir sonuçken, yapılan olumsuz yorumlardan çıkarımlar ile düzeltmeler yapılırsa bu saygınlığın katlanarak artacağı öngörülmektedir.

Ülkenin elçileri olarak tabir edilen turist rehberlerinin toplum gözünde daha iyi bir yere sahip olması için;

- Ne kadar entelektüel seviyesi artarsa artsın kibirli ve egoist davranışlardan kaçınması,

- Bilgi sahibi olunmayan konularda yanlış bilgi vermek yerine bilmiyorum demeyi veyahut "şu anda anımsayamiyorum, sizlere en doğru bilgiyi vermek adına sizi kısa bir süre bekletebilir miyim?" gibi nazik bir dil ile durumu kontrol altına alması,

- Halkın gözündeki komisyoncu damgasını engellemek adına fahiş oranlarda hakkedişler almaması,

- Her ne kadar turist taleplerinin can sıkıcı boyuta geldiği durumlar olmasına rağmen sabır ve sükunetlerini korumaları önerilmektedir.

Bu çalışma toplumun turist rehberi algısını yüzde yüz ortaya koymamakta ve yalnızca Ekşi sözlükte yer alan son 19 senelik yorumları içerdiği bilinmelidir. Literatürdeki birçok çalışma profesyonel turist rehberliğinin sorunlarını rehber açısından değerlendirirken, turist veya halk açısından bu duruma yaklaşan nadir çalışmalardan olması da oldukça önemlidir. Konuya dair daha detaylı bir sonuca ulaşmak için büyük ölçekli bir çalışma yapılması gelecek araştırmacılara önerilmek ile birlikte, yapılan bu çalışmanın toplumun bakış açısı hakkında fikir oluşturması açısından büyük öneme sahip olduğu düşünülmektedir.

Hakem Değerlendirmesi: Dis, bağmsız.

Teşekkür: Katkılarından dolayı hakemlere teşekkür ederim.

Destek Bilgisi: Herhangi bir kurum ve/veya kuruluştan destek alınmamıştır.

Çıkar Çatışması: Çıkar çatışması yoktur.

Etik Onayı: Bu çalışmanın tüm hazırlanma süreçlerinde etik kurallara riayet edildiğini yazar(lar) beyan eder. Aksi bir durumun tespiti halinde Güncel Turizm Araştırmaları Dergisi'nin hiçbir sorumluluğu olmayıp, tüm sorumluluk makale yazar(lar)ına aittir.

Bilgilendirilmiş Onam Formu: Tüm taraflar kendi rızaları ile çalışmaya dâhil olmuşlardır.

Etik Kurul Onayı: Çalışma kamuya açık ikincil verilerin kullanılmasiyla oluşturulmuştur.

Araştırmacıların Katkı Oranı: 1. yazar katkı oran1: \%100.

Veri Kullanılabilirlik Beyanı: Araştırma verileri paylaşılmamıştır. 


\section{KAYNAKÇA}

Alrawadieh, Z., Gürel, Ç., Dinçer, M. Z., ve İstanbullu Dinçer, F. (2020). The Impact of Emotional Dissonance on Quality of Work Life and Life Satisfaction of Tour Guides. Service Industries Journal, 40(1-2), 50-64. doi:10.1080/02642069.2019.1590554

Ap, J., ve Wong, K. K. (2001). Case Study on Tour Guiding: Professionalism, Issues and Problems. Tourism Management, 22(5), 551-563.

Cohen, E. (1985). The Tourist Guide: The Origins, Structure and Dynamics of a Role. Annals of Tourism Research, 12(1), 5-29.

Creswell, J. W. (2017). Araştırma Deseni: Nitel, Nicel ve Karma Yöntem Yaklaşımları Ankara: Eğiten Kitap.

Ekşisözlük. (t.y.). 19 Haziran 2020 tarihinde https://eksisozluk.com/ adresinden alındı

Gökdemir, S., ve Hacıoğlu, N. (2018). Turist Rehberlerinde Tükenmişlik ve Meslekten Ayrılma Niyeti. Balıkesir Üniversitesi Sosyal Bilimler Enstitüsü Dergisi, 511-541. doi:10.31795/baunsobed.437800

Güdü, D. Ö. (2014). Profesyonel Turist Rehberliği Mesleğinin Aile Yaşantısı Üzerindeki Etkisini Belirlemeye Yönelik Bir İnceleme. Turar Turizm ve Araştırma Dergisi, 3(2), 2141.

Hwang, J., Kim, J. J., Lee, J. H., ve Sahito, N. (2020). How to Form Wellbeing Perception and Its Outcomes in the Context of Elderly Tourism: Moderating Role of Tour Guide Services. International Journal of Environmental Research and Public Health, 17(3), 1029. https://doi.org/10.3390/ijerph17031029.

İlhan, Y., ve Soybalı, H. H. (2018). Turist Rehberlerinin Mesleki Sorunları Üzerine Bir Araştırma. Turist Rehberliği Dergisi, 13-23. doi:10.34090/tured.443615

Karamustafa, K., ve Kılıçhan, B. (2019). Delphi Yöntemi ile Profesyonel Turist Rehberliği Mesleğine İlişkin Sorunların Tespit Edilmesi. Afyon Kocatepe Üniversitesi Sosyal Bilimler Dergisi, 21(4), 1348-1365.

Kaya, M. (2020). Okul Müdürü Kavramına Yönelik Algıların Analizi: Bir Katılımcı Sözlük Fenomeni Ekşi Sözlük Örneği. Eurasian Journal of Teacher Education, 1(1), 70-81.

Kong, H., 2014. Are Tour Guides in China Ready for Ecotourism? An Importance-Performance Analysis of Perceptions and Performances. Asia Pacific Journal of Tourism Research. doi:10.1080/10941665.2012.724018

Köroğlu, Ö., Ulusoy Yıldırım, H., ve Kılıç, A. (2020). Kadın Turist Rehberlerinin Mesleki Sorunlarının Belirlenmesi. Mehmet Akif Ersoy Üniversitesi Sosyal Bilimler Enstitüsü Dergisi(31), 26-40. doi:10.20875/makusobed.586054

Liljeblad, J. (2020). Tour guides and the transnational promotion of human rights: Agency, structure and norm translators in responsible travel. Tourist Studies, 20(3), 314-335. doi: https://doi.org/10.1177/1468797620920991

Merriam, S. B. (2018). Nitel Araştırma Desen ve Uygulama İçin Bir Rehber Ankara: Nobel Yayıncilik. 
Söğüt, F. (2020). İnternet Sözlüklerinde Mekansal Ötekileştirme Üzerine Bir Araştırma: Ekşi Sözlük'te Esenyurt Başlığı Örneği. Gümüşhane Üniversitesi İletişim Fakültesi Elektronik Dergisi, 8(1), 45-68. doi:https://doi.org/10.19145/e-gifder.636956

Temizkan, R., ve Ar, H. (2017). Turist Rehberlerine Yönelik E-Şikayet Analizi. Akademik Bakış Dergisi (64), 273-285.

Tuncer, M. ve Taşkın, G. A. (2020). İnanç Turizmi Kapsamında Aksaray Somuncu Baba Külliyesi'nin YouTube Video Analizi, Türk Turizm Araştırmaları Dergisi, 4(3): 20552070.

TUREB. (Eş Zamanl1). Rehber İstatistikleri. 19 Haziran 2020 tarihinde http://tureb.org.tr/tr/RehberIstatistik/ adresinden alındı

TUREB. (2012, 06 2012). 6326 Sayılı Turist Rehberliği Mesleği Kanunu. 19 Haziran 2020 tarihinde http://www.tureb.org.tr/tr/Page/Detail/60 adresinden alınd1

Türker, A., ve Özaltın Türker, A. (2017). Pazarlama İletişim Kanalı Olarak Sosyal Medyanın Turist Rehberleri Tarafından Kullanımı. Sosyal Bilimler Dergisi, 4(14), 94-106. doi:https://doi.org/10.16990/SOBIDER.3585

Yıldırım, A., ve Şimşek, H. (2018). Sosyal Bilimlerde Nitel Araştırma Yöntemleri (11 b.). Ankara: Seçkin Yayıncılık.

Yıldırım, O. (2020). Katılımcı Kültürü Eleştirmek: “Dr. Younan Nowzaradan ile İlgili Caps, Tweet ve Ekşi Sözlük Entrylerinin Değerlendirilmesi". Kritik İletişim Çalışmaları Dergisi, 2(1), 13-22. 